\title{
Population structures and some growth properties of tench (Tinca tinca L., 1758) in Mogan Lake, Ankara, Turkey
}

\author{
Semra BENZER \\ Gazi University, Faculty of Education, Department of Science Education, Teknikokullar, Ankara, Turkey.
}

Summary: The present study was carried out to assess the population structure, growth and condition factor of tench, between June 2012 and June 2013, in Mogan Lake. The age of T. tinca caught from Mogan Lake ranged between I to VII years. The sex percentage was determined as $50 \%$ males, $42.92 \%$ females and $7.08 \%$ immature. Fork length of fish ranged from $9.2 \mathrm{~cm}$ to $36.5 \mathrm{~cm}$ and body weight of fish ranged from $9.4 \mathrm{~g}$ to $740 \mathrm{~g}$. The von Bertalanffy growth equations were: $\mathrm{L}_{\mathrm{t}}=412.141\left[1-\mathrm{e}^{-0.211}\right.$ $\left.{ }^{(t+1.82)}\right]$ for females, $\mathrm{L}_{\mathrm{t}}=397.517\left[1-\mathrm{e}^{-0.174(\mathrm{t}+2.89)}\right]$ for males and $\mathrm{L}_{\mathrm{t}}=384,001\left[1-\mathrm{e}^{-0,235(\mathrm{t}+0,88)}\right]$ for all individual; $\mathrm{W}_{\mathrm{t}}=1247.25\left[1-\mathrm{e}^{-}\right.$ $\left.{ }^{0.211(t+1.82)}\right]^{3.1232}$ for females, $\mathrm{W}_{\mathrm{t}}=1208.94\left[1-\mathrm{e}^{-0.174(\mathrm{t}+2.89)}\right]^{3.0293}$ for males and $\mathrm{W}_{\mathrm{t}}=1365,52\left[1-\mathrm{e}^{-0,235(\mathrm{t}+0,88)}\right]^{3,1217}$ for for all individual. The condition factor was calculated as 1.69, 1.68 and 1.67 for females, males and for all individual, respectively.

Key words: Growth, Mogan Lake, tench, von Bertalanffy's parameters.

\section{Mogan Gölü'nde yaşayan Kadife Balığı (Tinca tinca L., 1758)'nın populasyon yapısı ve büyüme özellikleri}

Özet: Bu araştırmada Haziran 2012 ve Haziran 2013 tarihleri arasında Mogan Gölü’nde yaşayan Kadife Balığı’'nın yaş, büyüme özellikleri ve kondüsyon faktörü incelenmiştir. Mogan Gölü’nde yakalanan T. tinca bireylerinin I-VII yaşları arasında dağ 1 lım gösterdiği tespit edilmiştir. Populasyonun \% 50'sini erkek, \% 42,92'sini dişi ve \% 7.08'sini de immature bireylerin oluşturduğu saptanmıştır. Boy dağılımı $9,2 \mathrm{~cm}$ ile $36,5 \mathrm{~cm}$ ve ağılık dağılımı ise $9,4 \mathrm{~g}$ ile $740 \mathrm{~g}$ arasında değişim göstermektedir. Von Bertalanffy büyüme denklemlerine göre boyca büyüme dişiler için $\mathrm{L}_{t}=412,141\left[1-\mathrm{e}^{-0,211(\mathrm{t}+1,82)}\right]$, erkekler için $\mathrm{L}_{t}=397,517[1$ $\left.\mathrm{e}^{-0,174(\mathrm{t}+2,89)}\right]$ ve tüm bireyler için $\mathrm{L}_{\mathrm{t}}=384,001\left[1-\mathrm{e}^{-0,235(\mathrm{t}+0,88)}\right]$; ağırlıkça büyüme dişiler için $\mathrm{W}_{\mathrm{t}}=1247,25\left[1-\mathrm{e}^{-0,211(\mathrm{t}+1,82)}\right]^{3,1232}$ erkekler için $\mathrm{W}_{\mathrm{t}}=1208,94\left[1-\mathrm{e}^{-0,174(\mathrm{t}+2,89)}\right]^{3,0293}$ ve tüm bireyler için $\mathrm{W}_{\mathrm{t}}=1365,52\left[1-\mathrm{e}^{-0,235(\mathrm{t}+0,88)}\right]^{3,1217}$, dir. Kondüsyon faktörü değerleri dişi, erkek ve tüm bireyler için sırasıyla 1,69; 1,68 ve 1,67 olarak hesaplanmıştır.

Anahtar sözcükler: Büyüme, kadife balığı, Mogan Gölü, von Bertalanffy parametresi.

\section{Introduction}

In Turkey, Cyprinidae are the richest and the most important family of fish, and its members are distributed world-wide. These family members are distributed widely in fresh water sources (12). Tench, Tinca tinca (L.), is widely distributed in Europe and Asia, and has been introduced into the America, South Africa and Austria (22).

Tinca tinca, is a fish with an economic importance which shows a large distribution in inland waters of Turkey. They are highly resistance against external influences and diseases in spite of their body covered with thin scales and a mucus layer (12). Due to they contact the mud of lake bottom continuously, they have an important role in the determination of mineralization (10). They also prevent the transition of inorganic nutrient salts, nitrogen and phosphorus accumulated in sediment to the water in eutrophic lakes because they feed on aquatic plants (16). Some of the researches related to Tinca tinca in Turkey and in the world are as follows:

The growth properties of tench (Tinca tinca L., 1758) was investigated in Kesikköprü Dam Lake (3), Vegoritis Lake (23), Lake Dgal Wielki (19), Bayındır Dam Lake (4), Çivril Lake (6), Beyşehir Lake (1, 7), Hirfanlı Dam Lake (8), two gravel pit lakes (25), Seyhan Dam Lake (11), Kapulukaya Dam Lake $(18,9)$, Çamkoru Pond (13) and Trasimeno Lake (20).

Ecological factors affect the biological and reproduction characteristics of fish populations and so these kinds of investigations should be carried out periodically.

The main purpose of the present investigation was to study growth in Tinca tinca. Thus, the present study provides the first information on the population structure (age, growth and sex ratio) of the tench from Cyprinidae family (Tinca tinca L., 1758) in Mogan Lake. 


\section{Materials and Methods}

Mogan Lake is located about $20 \mathrm{~km}$ south of Ankara, capital of Turkey, and lies within the coordinates of $39^{\circ} 44^{\prime} 40^{\prime \prime} \mathrm{N}$ and $39^{\circ} 47^{\prime} 45^{\prime \prime} \mathrm{N}$ latitudes and $32^{\circ} 46^{\prime} 30^{\prime \prime} \mathrm{E}$ and $32^{\circ} 49^{\prime} 30^{\prime \prime}$ E longitudes (Figure 1). It is near the Gölbaş1 town which has undergone considerable development by the increased population and settlement in recent years (2).

This study was carried out on 226 (97 females, 113 males and 16 immature) caught by using a gill nets (18 $\mathrm{mm}-55 \mathrm{~mm}$ mesh sizes) in Mogan Lake. Samplings were done every month (12-21 individual) from June 2012 to June 2013 with a random method. The fish samples were transported to the laboratory to record the fork length (FL) to the nearest $0.1 \mathrm{~cm}$ and body weight (BW) to the nearest $0.1 \mathrm{~g}$. The gender of the fish was determined from the gonads. Scales were sampled from each specimen for age determination according to Lagler (14).

Growth was estimated using the von Bertalanffy growth curve model (24) $\mathrm{L}_{\mathrm{t}}=\mathrm{L}_{\infty}\left[1-\mathrm{e}^{-\mathrm{K}(\mathrm{t}-\mathrm{t})}\right]$ and weight $\left.\mathrm{W}_{\mathrm{t}}=\mathrm{W}_{\infty}\left[1-\mathrm{e}^{-\mathrm{K}(\mathrm{t}-\mathrm{t})}\right)\right]^{\mathrm{b}}$ where $\mathrm{L}_{\mathrm{t}}=$ the fork length $(\mathrm{cm})$ at age $t, L_{\infty}=$ the asymptotic length (theoretical maximum length), $\mathrm{k}=$ the Brody growth coefficient (proportional to rate at which $\mathrm{L}_{\infty}$ is reached), $\mathrm{t}=$ the age (years), $\mathrm{t}_{0}=$ the age at zero length, e is the base of natural $\log (2.71828)$, $\mathrm{W}_{t}$ is the weight of the fish in $g$ at age $t, \mathrm{~W}_{\infty}$ is the asymptotic weight of (theoretical maximum weight) the fish in $\mathrm{g}$ and $\mathrm{b}$ is the constant in the length-weight relationship. The von Bertalanffy growth parameters were estimated for males and females separately as well as for both sexes combined. The relationship between FL and BW was calculated separately for each sex with $\log _{10}$-transformed data (15). The condition factors (CF) of fish was determined using the formula $\left(\mathrm{W} / \mathrm{L}^{3}\right) \times 100$ (21), where $\mathrm{W}=$ body weight and $\mathrm{L}=$ body length.

Statistical analysis of data was carried out using SPSS statistical package program for Windows Ver. 18.

\section{Results}

The age of 226 specimens of Tinca tinca caught from Mogan Lake ranged between I to VII years (Figure 2 a) and among the different age groups, III and IV year classes were dominant. There were the highest individuals in March (9.29\%) while there were the lowest individuals in January (5.31\%) (Figure 2 b). There were about 42.92 $\%$ females and $50 \%$ males (sex ratio 1:1.16), and differences among different age groups were not significant $(\mathrm{p}>0.05)$.

The mean FL, mean BW and CF of male and female fish in different age groups is presented in Table 1. Mean FL (cm, min-max), mean BW (g, min-max) and mean CF (value, min-max) were founded 137.25 (82$215), 62.35$ (8.2-178.4) and 1.5143 (1.3087-1.7951) for I age group. Females IV, V, VI and VII age groups were longer than males. Males II and III age groups were longer than females. The differences between the sexes were insignificant in all groups $(p>0.05)$. Age-length relationships of females and males are plotted in Figure 3 with the respective equations indicated and differences between sexes were insignificant in all age groups $(p>0.05)$. Male and female age-weight relationships are drawn in Figure 4. While weight of females was higher than for males in age groups IV, V, VI and VII, weight of males was higher than for females in age group II and III. Females grew to a greater asymptotic $\left(\mathrm{W}_{\infty}\right)$ weight than the males (Figure 5).

Length-weight relationships were calculated using the data of all fish samples. The relationship was $\mathrm{W}=$ $0.00000849 \mathrm{~L}^{3.1232}\left(\mathrm{R}^{2}=0.91\right)$ for females, $\mathrm{W}=$ $0.00001426 \mathrm{~L}^{3.0293}\left(\mathrm{R}^{2}=0.90\right)$ for males and $\mathrm{W}=$ $0.00000857 \mathrm{~L}^{3.1217}$ for all individual. The $\mathrm{b}$ value for females was higher than for males. Length-weight curves for males and females are drawn in Figure 5.

While CF of females was higher than for males in age groups IV, V and VI, CF of males was higher than for

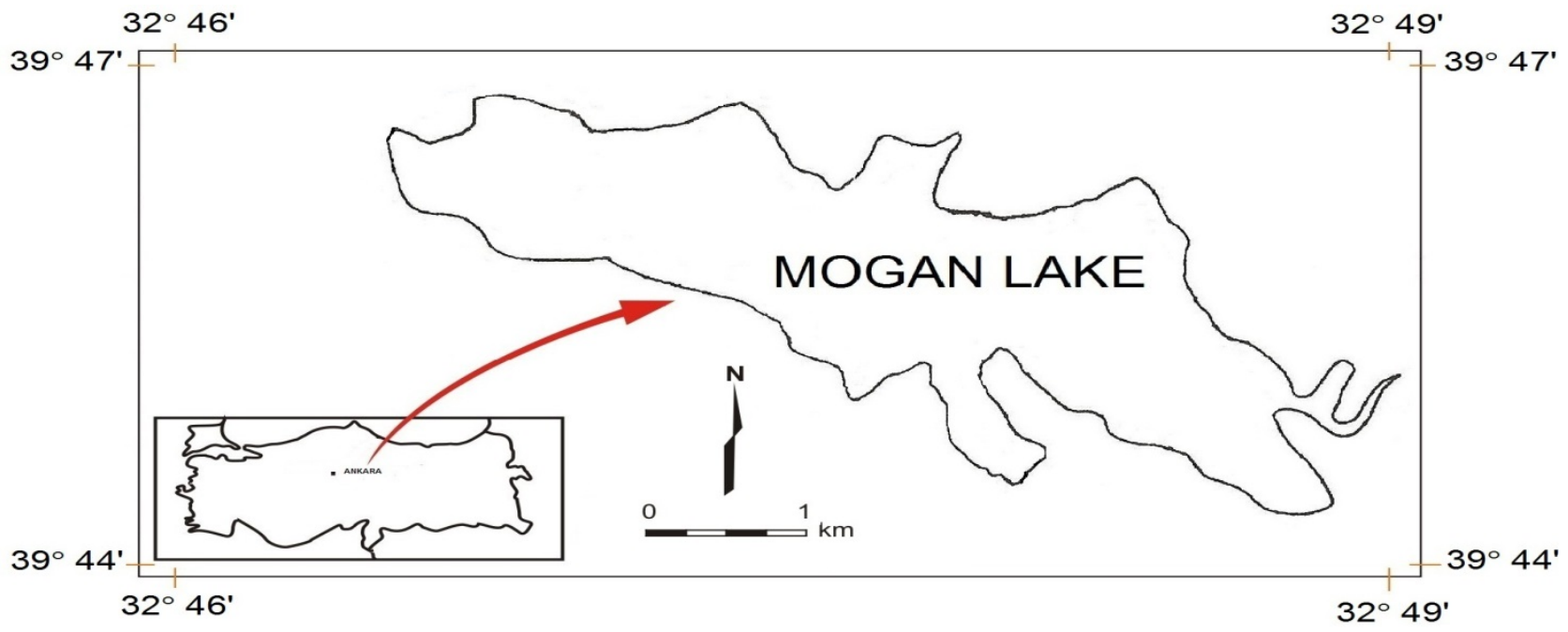

Figure 1. Map of Mogan Lake.

Şekil 1. Mogan Gölü Haritası. 

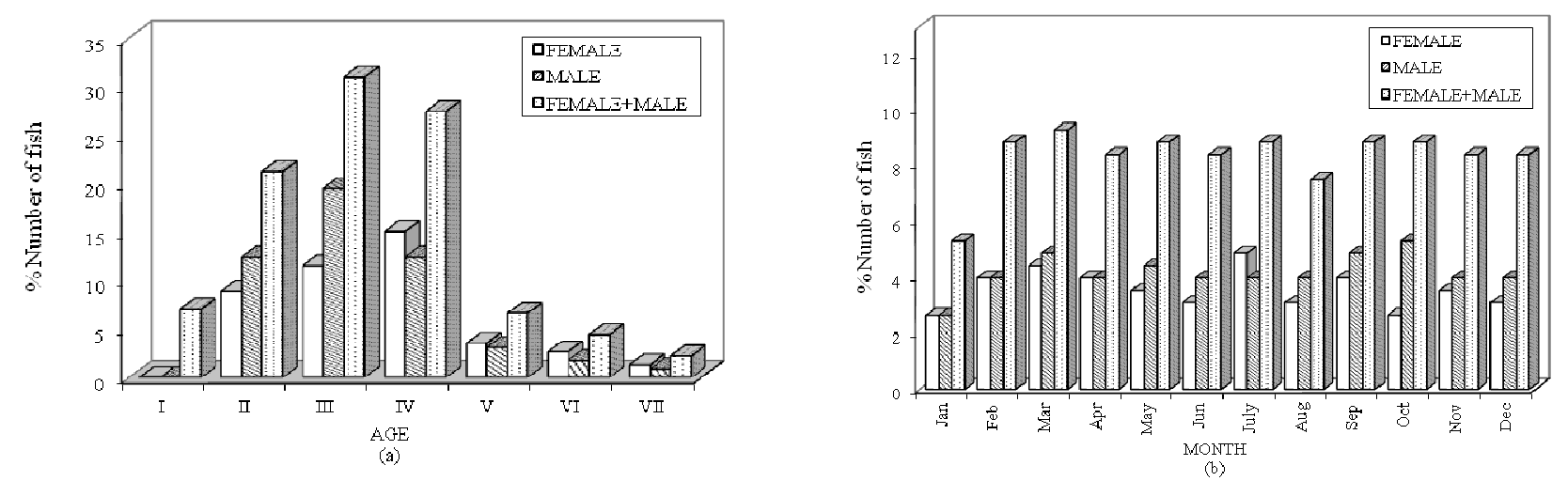

Figure 2. The percent (\%) distribution of T. tinca according to their age, sex (a) and (b) month, sex.

Şekil 2. Yaş (a) ve aylara (b) göre cinsiyet T. tinca yüzde (\%) dağılımı.
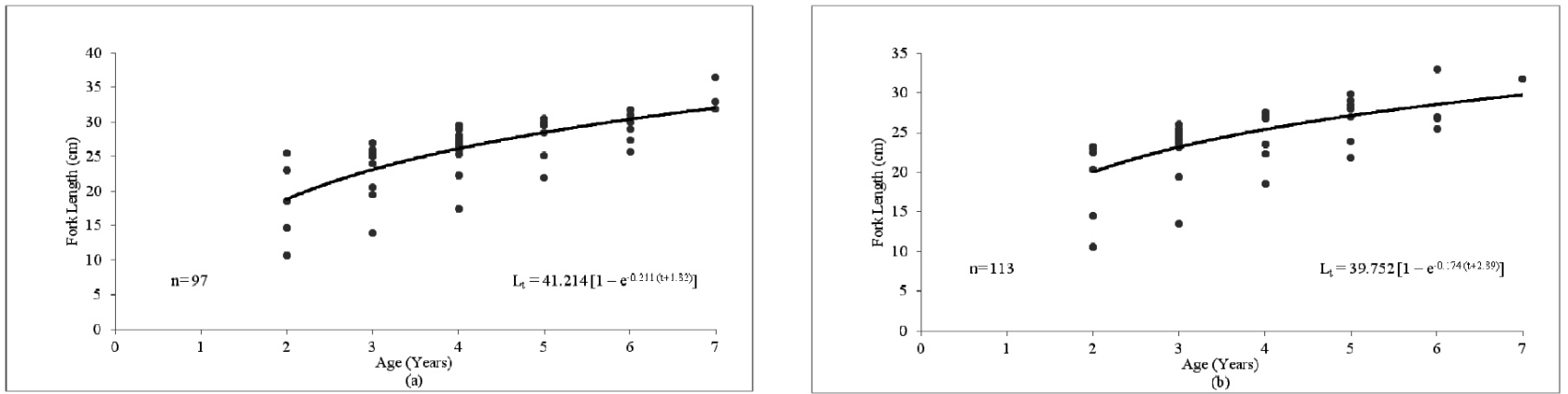

Figure 3. Age-length relationships in female (a) and male (b) T. tinca. Şekil 3. T. tinca'nın yaş-boy ilişkileri a: Dişi, b: Erkek.
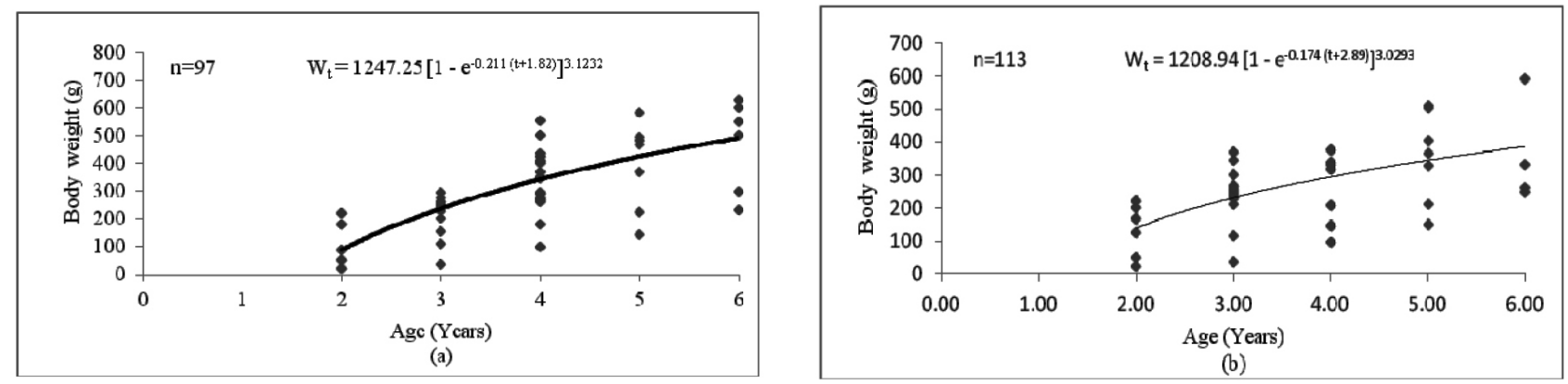

Figure 4. Age-weight relationships in female (a) and male (b) T. tinca. Şekil 4. T. tinca'nın yaş-ağırlık ilişkileri a: Dişi, b: Erkek.
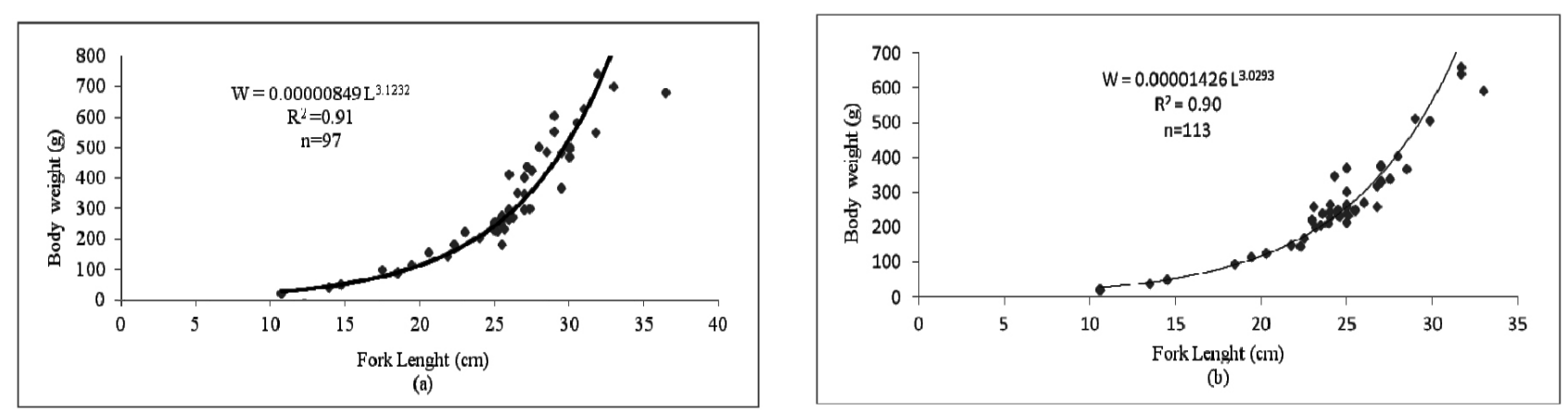

Figure 5. Length-weight relationships in female (a) and male (b) T. tinca. Şekil 5. T. tinca'nın boy-ağırlık ilişkileri a: Dişi, b: Erkek. 
Table 1. Mean fork length (FL, cm), mean Body weight (BW, g), mean condition factor (CF) for different age groups of $T$. tinca males and females in Mogan Lake.

Tablo 1. Mogan Gölündeki T. tinca bireylerine (erkek ve dişi) ait yaş gruplarına göre ortalama çatal boy (FL, cm), vücut ağırlığı $(\mathrm{BW}, \mathrm{g})$, kondüsyon faktörü $(\mathrm{CF})$.

\begin{tabular}{|c|c|c|c|c|}
\hline \multirow[b]{2}{*}{$\begin{array}{l}\text { Age } \\
\text { (Year) }\end{array}$} & \multirow[b]{2}{*}{$\mathrm{N}$} & \multicolumn{3}{|c|}{ Parameters } \\
\hline & & $\begin{array}{c}\mathrm{FL} \pm \mathrm{SE} \\
\text { (min.-max.) }\end{array}$ & $\begin{array}{c}\mathrm{BW} \pm \mathrm{SE} \\
\text { (min.-max.) }\end{array}$ & $\begin{array}{c}\mathrm{CF} \pm \mathrm{SE} \\
\text { (min.-max.) }\end{array}$ \\
\hline \multicolumn{5}{|c|}{ Female } \\
\hline I & - & - & - & - \\
\hline II & 20 & $\begin{array}{c}18.48 \pm 5.51 \\
10.40-25.50\end{array}$ & $\begin{array}{l}112.44 \pm 78.39 \\
21.80-221.00\end{array}$ & $\begin{array}{l}1.52 \pm 0.26 \\
1.09-1.82\end{array}$ \\
\hline III & 26 & $\begin{array}{c}23.65 \pm 3.53 \\
13.10-27.00\end{array}$ & $\begin{array}{l}218.03 \pm 72.13 \\
37.90-297.00\end{array}$ & $\begin{array}{l}1.56 \pm 0.09 \\
1.44-1.79\end{array}$ \\
\hline IV & 34 & $\begin{array}{c}26.06 \pm 2.66 \\
18.00-29.50\end{array}$ & $\begin{array}{c}338.02 \pm 111.59 \\
94.50-553.00\end{array}$ & $\begin{array}{l}1.84 \pm 0.29 \\
1.43-2.34\end{array}$ \\
\hline V & 8 & $\begin{array}{c}28.13 \pm 3.02 \\
22.00-30.05\end{array}$ & $\begin{array}{l}406.18 \pm 150.20 \\
138.50-581.00\end{array}$ & $\begin{array}{l}1.72 \pm 0.29 \\
1.36-2.09\end{array}$ \\
\hline VI & 6 & $\begin{array}{c}29.15 \pm 2.28 \\
24.90-31.08\end{array}$ & $\begin{array}{l}468.66 \pm 164.46 \\
250.00-627.00\end{array}$ & $\begin{array}{l}1.83 \pm 0.41 \\
1.37-2.46\end{array}$ \\
\hline VII & 3 & $\begin{array}{c}33.80 \pm 2.40 \\
31.90-36.50\end{array}$ & $\begin{array}{c}706.66 \pm 30.55 \\
680.00-740.00\end{array}$ & $\begin{array}{l}1.88 \pm 0.44 \\
1.40-2.28\end{array}$ \\
\hline \multicolumn{5}{|c|}{ Male } \\
\hline I & - & - & - & - \\
\hline II & 28 & $\begin{array}{c}19.85 \pm 4.74 \\
10.10-23.20\end{array}$ & $\begin{array}{l}144.58 \pm 77.05 \\
23.90-223.00\end{array}$ & $\begin{array}{l}1.68 \pm 0.16 \\
1.48-1.93\end{array}$ \\
\hline III & 44 & $\begin{array}{c}23.89 \pm 2.62 \\
12.90-26.00\end{array}$ & $\begin{array}{l}242.50 \pm 65.42 \\
36.90-369.00\end{array}$ & $\begin{array}{l}1.72 \pm 0.27 \\
1.36-2.41\end{array}$ \\
\hline IV & 28 & $\begin{array}{c}24.65 \pm 3.18 \\
17.80-27.50\end{array}$ & $\begin{array}{c}259.30 \pm 102.41 \\
98.00-376.00\end{array}$ & $\begin{array}{l}1.62 \pm 0.16 \\
1.32-1.91\end{array}$ \\
\hline $\mathrm{V}$ & 7 & $\begin{array}{c}26.87 \pm 2.94 \\
24.50-29.90\end{array}$ & $\begin{array}{l}353.95 \pm 136.84 \\
160.50-511.00\end{array}$ & $\begin{array}{l}1.72 \pm 0.22 \\
1.45-2.09\end{array}$ \\
\hline VI & 4 & $\begin{array}{c}28.07 \pm 3.35 \\
26.80-33.00\end{array}$ & $\begin{array}{l}358.17 \pm 160.20 \\
260.00-592.00\end{array}$ & $\begin{array}{l}1.55 \pm 0.15 \\
1.35-1.68\end{array}$ \\
\hline VII & 2 & $\begin{array}{c}31.70 \pm 0.35 \\
31.65-31.70\end{array}$ & $\begin{array}{c}650.00 \pm 14.14 \\
640.00-660.00\end{array}$ & $\begin{array}{l}2.04 \pm 0.04 \\
2.01-2.07\end{array}$ \\
\hline
\end{tabular}

$\mathrm{N}$, number of fish;

FL, BW and CF significance level ( $\mathrm{p}$ value) is found $\mathrm{p}>0.05$.

females in age group II, III and VII. The differences between sexes were insignificant ( $\mathrm{p}>0.05$, t-test; Table 1, Figure 6). The condition factor was calculated as 1.69 , 1.68 and 1.67 for females, males and all individual respectively.

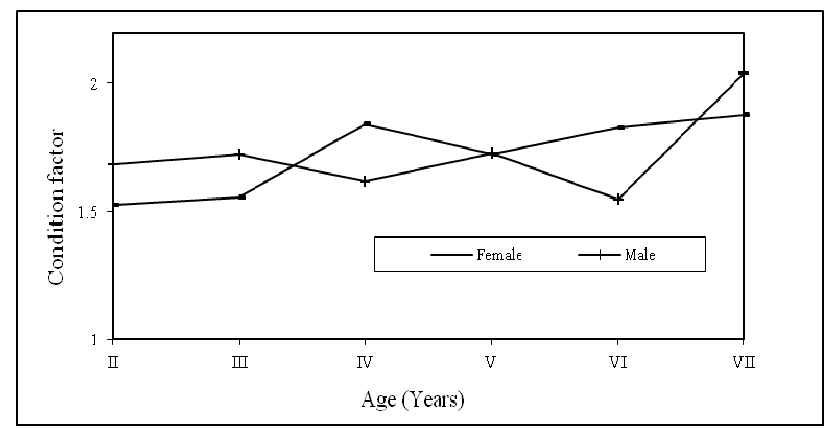

Figure 6. Mean condition factor according to age and sex of $T$. tinca.

Şekil 6. T. tinca'da yaş ve cinsiyetine göre kondüsyon faktörü ortalamasi.

\section{Discussion and Conclusion}

The female male sex ratio of tench in Mogan Lake was $1: 1.16$, and similar to the $1: 1$ ratio expected for most fish species (5). This is also in agreement with the value reported in the same species by Alaş and Ak (1) and Balık et al. (7) for Beyşehir Lake. However, Balık et al. (6) and Ergüden and Göksu (11) reported higher ratios for females:males (1:1.61 and 1:1.53). Although the sex ratio in most of the species was close to 1 , this may vary from species to species, differing from one population to another of the same species, and may vary year after year within the same population.

At early life stages the ratio of males is higher, but at later stages the female ratio is higher (17) and the results are in agreement with this study and the findings of $(1,6,11)$. Some of the researches are founded that the number of female is higher than males in all ages group (13). Some of the researches are founded that at early life stages the ratio of males is higher (18). 
Table 2. Age structure, parameters of length-weight relationship ( $\mathrm{a}$ and $\mathrm{b}$ ), growth $\left(\mathrm{L}_{\infty}, \mathrm{K}, \mathrm{t}_{0}\right)$ and $\mathrm{CF}$ of T. tinca.

Tablo 2. T. tinca bireylerine ait yaş, boy-ağırlık ilişkisi (a ve b), büyüme $\left(\mathrm{L}_{\infty}, \mathrm{K}, \mathrm{t}_{0}\right)$ parametreleri ve $\mathrm{CF}$.

\begin{tabular}{|c|c|c|c|c|c|c|c|c|c|}
\hline $\begin{array}{l}\text { References } \\
\text { Area }\end{array}$ & $\begin{array}{c}\text { Age } \\
\text { (Years) }\end{array}$ & $\mathrm{N}$ & $\mathrm{a}$ & $\mathrm{b}$ & $r^{2}$ & $\mathrm{~L}_{\infty}$ & $\mathrm{k}$ & $\mathrm{t}_{0}$ & $\mathrm{CF}$ \\
\hline $\begin{array}{l}\text { Wright and Giles (25) } \\
\text { Main and St.Peter Lake }\end{array}$ & 7 & 176 & - & - & - & $\begin{array}{l}57.30^{\mathrm{a}} \\
58.60^{\mathrm{b}}\end{array}$ & $\begin{array}{l}0.122^{\mathrm{a}} \\
0.144^{\mathrm{b}}\end{array}$ & - & - \\
\hline $\begin{array}{l}\text { Altındağ et al. (3) } \\
\text { Kesikköprü Dam Lake } \\
\text { Crotia }\end{array}$ & 6 & 105 & -2.034 & 3.174 & - & $57.8^{c}$ & $0.126^{\mathrm{c}}$ & $-0983^{c}$ & $1.95^{\mathrm{c}}$ \\
\hline $\begin{array}{l}\text { Altındağ et al. (4) Bayındır } \\
\text { Dam Lake }\end{array}$ & 5 & $\begin{array}{c}49 \\
51 \\
100\end{array}$ & 2.031 & 3.175 & - & $\begin{array}{l}41.76^{\mathrm{a}} \\
36.97^{\mathrm{b}} \\
57.76^{\mathrm{c}}\end{array}$ & $\begin{array}{l}0.251^{\mathrm{a}} \\
0.377^{\mathrm{b}} \\
0.126^{\mathrm{c}}\end{array}$ & $\begin{array}{l}-0.983^{\mathrm{b}} \\
-0.377^{\mathrm{b}} \\
-1.684\end{array}$ & $\begin{array}{l}1.99^{\mathrm{a}} \\
1.92^{\mathrm{b}} \\
1.95^{\mathrm{c}}\end{array}$ \\
\hline $\begin{array}{l}\text { Balık et al. (6) } \\
\text { Çivril Lake }\end{array}$ & 5 & 506 & 0.018 & 3.01 & & $33.85^{\mathrm{c}}$ & $0.284^{c}$ & $-0.895^{\mathrm{c}}$ & - \\
\hline $\begin{array}{l}\text { Alaş and Ak (1) Beyşsehir } \\
\text { Lake }\end{array}$ & 8 & $\begin{array}{l}110 \\
100\end{array}$ & $\begin{array}{l}0.012 \\
0.013\end{array}$ & $\begin{array}{l}3.099 \\
3.072\end{array}$ & $\begin{array}{l}0.94 \\
0.95\end{array}$ & $\begin{array}{l}41.36^{\mathrm{a}} \\
44.23^{\mathrm{b}}\end{array}$ & $\begin{array}{l}0.152^{\mathrm{a}} \\
0.118^{\mathrm{b}}\end{array}$ & $\begin{array}{l}-3.140^{\mathrm{b}} \\
-3.675^{\mathrm{b}}\end{array}$ & $\begin{array}{l}- \\
-\end{array}$ \\
\hline $\begin{array}{l}\text { Balık et al. (7) } \\
\text { Beyşehir Lake }\end{array}$ & 8 & $\begin{array}{l}1795 \\
1865 \\
3360\end{array}$ & $\begin{array}{l}0.015 \\
0.015 \\
0.015\end{array}$ & $\begin{array}{l}3.001 \\
2.999 \\
2.999\end{array}$ & $\begin{array}{c}0.99 \\
0.99 \\
-\end{array}$ & $\begin{array}{l}55.4 \mathrm{a} \\
51.4^{\mathrm{b}} \\
54.2^{\mathrm{c}}\end{array}$ & $\begin{array}{l}0.130 \mathrm{a} \\
0.145^{\mathrm{b}} \\
0.135^{\mathrm{c}}\end{array}$ & $\begin{array}{l}-1.058^{\mathrm{b}} \\
-1.095^{\mathrm{b}} \\
-1.028^{\mathrm{c}}\end{array}$ & $\begin{array}{c}- \\
- \\
1.513^{\mathrm{c}}\end{array}$ \\
\hline $\begin{array}{l}\text { Ergüden and Göksu (11) } \\
\text { Seyhan Lake }\end{array}$ & 5 & $\begin{array}{c}506 \\
778 \\
1284\end{array}$ & 0.063 & 2.51 & 0.981 & $\begin{array}{l}47.32^{\mathrm{a}} \\
40.70^{\mathrm{b}} \\
50.86^{\mathrm{c}}\end{array}$ & $\begin{array}{c}0.128^{\mathrm{a}} \\
0.185^{\mathrm{b}} \\
0.1120^{\mathrm{c}}\end{array}$ & $\begin{array}{l}-1.428^{\mathrm{a}} \\
-0.952^{\mathrm{b}} \\
-1.551^{\mathrm{c}}\end{array}$ & $1.58^{\mathrm{c}}$ \\
\hline $\begin{array}{l}\text { Innal (13) } \\
\text { Çamkoru Pond }\end{array}$ & 8 & $\begin{array}{l}131 \\
132 \\
304\end{array}$ & 0.013 & 3.013 & - & - & - & - & - \\
\hline $\begin{array}{l}\text { Okgerman et al. (18) } \\
\text { Kapulukaya Dame Lake }\end{array}$ & 7 & 150 & $\begin{array}{l}0.004 \\
0.023\end{array}$ & $\begin{array}{l}3.1752 \\
2.9571\end{array}$ & $\begin{array}{l}0.96 \\
0.97\end{array}$ & $\begin{array}{l}45.11^{\mathrm{a}} \\
44.61^{\mathrm{b}}\end{array}$ & $\begin{array}{l}0.1560^{\mathrm{a}} \\
0.1617^{\mathrm{b}}\end{array}$ & $\begin{array}{l}-1.979^{b} \\
-1.821^{b}\end{array}$ & - \\
\hline $\begin{array}{l}\text { This study } \\
\text { Mogan Lake }\end{array}$ & 6 & $\begin{array}{c}97 \\
113 \\
226\end{array}$ & $\begin{array}{l}0.000009 \\
0.000015 \\
0.000009\end{array}$ & $\begin{array}{l}3.1232 \\
3.0293 \\
3.1217\end{array}$ & $\begin{array}{l}0.91 \\
0.90 \\
0.91\end{array}$ & $\begin{array}{l}41.214^{\mathrm{a}} \\
39.751^{\mathrm{b}} \\
38.401^{\mathrm{c}}\end{array}$ & $\begin{array}{l}0.211^{\mathrm{a}} \\
0.170^{\mathrm{b}} \\
0.235^{\mathrm{c}}\end{array}$ & $\begin{array}{l}1.820^{\mathrm{a}} \\
2.890^{\mathrm{b}} \\
0.880^{\mathrm{c}}\end{array}$ & $\begin{array}{l}1.69^{\mathrm{a}} \\
1.68^{\mathrm{b}} \\
1.67^{\mathrm{c}}\end{array}$ \\
\hline
\end{tabular}

${ }^{\mathrm{a}}$ female, ${ }^{\mathrm{b}}$ male; ${ }^{\mathrm{c}}$ all individual, $\mathrm{N}$, number of fish;

Most of the samples studied in the present study belonged to III year age group. Benzer et al. (8), Innal (13), Okgerman et al. (18), reported a similar situation for Hirfanlı Dam Lake, Çamkoru Pond, Kapulukaya Dam Lake populations. While Alaş and Ak (1) and Ergüden and Göksu (11) found that most of the samples were in the II year age group for Beyşehir Lake and Seyhan Dam Lake, Balık et al. (6) found that most of the samples were in the I year age group for Çivril Lake.

Males were longer and heavier than females in II and III year ages groups. IV, V, VI and VII year ages group females were found heavier and longer than males. Males were longer and heavier at earlier life stages, while females were longer and heavier at later stages (3). Alaş and Ak (1), Okgerman et al. (18) and Innal (13) found that females longer than males in all ages for Beyşehir Lake, Çamkoru Pond and Kapulukaya Dam Lake. Alaş and $\mathrm{Ak}$ (1) found that females heavier than males in all ages for Beyşehir Lake.

Variations in fish growth in terms of length and weight can be explained as an adaptive response to different ecological conditions (17). The von Bertalanffy growth equations were: $\mathrm{L}_{\mathrm{t}}=412.141\left[1-\mathrm{e}^{-0.211(\mathrm{t}+1.82)}\right]$ for females, $\mathrm{L}_{\mathrm{t}}=397.517\left[1-\mathrm{e}^{-0.174(\mathrm{t}+2.89)}\right]$ for males and $\mathrm{L}_{\mathrm{t}}=$ $384,001\left[1-\mathrm{e}^{-0,235}{ }^{(\mathrm{t}+0,88)}\right]$ for all individual; $\mathrm{W}_{\mathrm{t}}=$ $1247,25\left[1-\mathrm{e}^{-0.211(\mathrm{t}+1.82)}\right]^{3.1232}$ for females, $\mathrm{W}_{\mathrm{t}}=1208.94[1$ $\left.-\mathrm{e}^{-0.174(\mathrm{t}+2.89)}\right]^{3.0293}$ for males and $\mathrm{W}_{\mathrm{t}}=1365,52\left[1-\mathrm{e}^{-0,235}\right.$ $\left.{ }^{(t+0,88)}\right]^{3,1217}$ for all individual.

While some earlier studies have reported similar theoretical maximum length $(1,4)$, other studies were different $(3,6,7,11,18,25)$. This variation may be due to different stages in ontogenetic development, as well as differences in condition, length, age, sex and gonadal development of fish (21). Geographic location and some environmental conditions such as temperature, organic matter, quality of food, time of capture, stomach fullness, disease, parasitic loads (5).

CF of tench varied from 1.3193 to 2.4183 in male; from 1.0904 to 2.4683 in female and from 1.0904 to 2.4683 in all individual. Maximum CF was found as 2.4683 (Table 2, Figure 6). The results are in agreement with some earlier reports $(7,11)$, while it differed from studies carried out by $(3,4)$.

CF of Tinca tinca differed age and gender of fish (Table 1). CF values of $S$. Tinca tinca in the Mogan Lake was recorded to be lower than 3 . 
The slope (b) values of the length-weight relationship in both gender is found as a 3.1217. Similar b values for Tinca tinca were reported by Altındağ et al. $(3,4)$; Balık et al. (6, 7); Alaş and Ak (1); Innal (13); Okgerman et al. (18), but it differed from those found by Ergüden and Göksu (11). The b value is often 3.0 and generally between 2.5 and 3.5. As the fish grows, changes in weight are relatively greater than changes in length, due to approximately cubic relationships between fish length and weight. The $b$ values in fish is species specific and varies with sex, age, seasons, physiological conditions, growth increment and nutritional status of fish $(5,21)$.

In conclusion this is the study presenting the biological features of Tinca tinca population living in Mogan Lake such as, growth, gender ratio, age distribution. It is recommended that the necessary steps should be taken asap to protect the Tinca tinca population in the lake after investigating its stock situation and breeding and feeding behaviors.

\section{References}

1. Alaş A, Ak A (2007): Investigation of Some Population Parameters of the Tench (Tinca tinca L., 1758) Inhabiting Beyşehir Lake (Konya-Turkey). Turk J Fish Aquat Sc, 7, 139-145.

2. Anonymous (1992): Report on Lake Mogan. General Directorate of State Hydraulic Works. pp 212, Ankara.

3. Altındağ A, Yiğit S, Ahıska S, Özkurt Ş (1998): Kesikköprü Baraj Gölü’ndeki Kadife Balığının (Tinca tinca L., 1758) Büyüme Özellikleri. Turk J Zool, 22, 311318.

4. Altındağ A, Shah SL, Yigit S (2002): The growth features of tench (Tinca tinca L., 1758) in Bayındır Dam Lake, Ankara, Turkey. Turk J Zool, 26, 385-391.

5. Bagenal TB, Tesch FW (1978): Age and growth. In: Methods for assessment of fish production in fresh waters. IBP Handbook No. 3. T. Bagenal (Ed.). Blackwell Scientific Publications, Oxford, pp. 101-136.

6. Balık S, Sarı HM, Ustaoğlu MR, Ilhan A (2004): The structure, mortality and growth of the tench (Tinca tinca L., 1758) in Çivril Lake, Denizli, Turkey. Turk J Vet Anim Sci, 28, 973-979.

7. Balık İ, Çubuk H, Çınar Ş, Özkök R (2009): Population structure, growth, mortality and estimated stock size of the introduced tench, Tinca tinca (L.), population in Lake Beyşehir, Turkey. J Appl Ichthyol, 25, 206-210.

8. Benzer ŞS, Gül A, Yılmaz M (2009): Growth Properties of Tench (Tinca tinca, L., 1758) Living in Hirfanl Reservoir (Kirşehir, Turkey). Iran J Fish Sci, 8, 219-224.

9. Benzer S, Gül A, Yılmaz M (2010): Growth Properties of Tench (Tinca tinca, L., 1758) Living in Kapulukaya Dam Lake, Turkey. Kastamonu Educ J, 18, 839-848.

10. Demirsoy A (1998): Basic Rules of Life, Vertebrates, (in Turkish). Hacettepe University Publication. III A/55: pp 684.
11. Erguden Alagoz S, Goksu MZL (2010): Age, growth and sex ratio of tench Tinca tinca (L., 1758) in Seyhan Dam Lake, Turkey. J Appl Ichthyol, 26, 546 -549.

12. Geldiay R, Balık S (1996): The freshwater fishes of Turkey, (in Turkish). College of Fisheries. Ege University Publications No:46.

13. Innal D (2010): Population Structures and Some Growth Properties of Three Cyprinid Species [Squalius cephalus (Linnaeus, 1758); Tinca tinca (Linnaeus, 1758) and Alburnus escherichii Steindachner, 1897] Living in Camkoru Pond (Ankara-Turkey), Kafkas Univ Vet Fak Derg, 16, 297-304.

14. Lagler KF (1966): Freshwater fishery biology. W.M.C. Brown Company, Dubuque, IA. 421.

15. Le Cren ED (1951): The length-weight relationship and seasonal cyclein gonad weight and condition in Perch, Perca fluviatilis. J Anim Ecol, 20, 201-219.

16. Michaels VK (1988): Carp Farming. Printed in Great Britain by Henry Ling Ltd. The Dorset Press, Dorchester, $200 \mathrm{pp}$.

17. Nikolsky GV (1963): The ecology of fishes (translated by L. Birkett). Academic Press, London, pp 352.

18. Okgerman H, Yiğit Atasagun S, Oral M (2010): The Age And Growth Features of Tench (Tinca tinca L., 1758) in Kapulukaya Dam Lake, Central Anatoliae, Turkey. J Anim Vet Adv, 9, 1833-1838.

19. Pimpica E, Pinos B (1999): Growth of Female Tench, Tinca tinca (L.,1758) in Lake Dgal Wielki, NE Poland. Folia Zool, 48, 143-148.

20. Pompei L, Franchi E, Giannetto D, Lorenzoni M (2012): Growth and reproductive properties of tench, Tinca tinca Linnaeus, 1758 in Trasimeno Lake (Umbria, Italy), Knowl Manag Aquat Ec, 406, 1-13.

21. Ricker WE (1975): Computation and interpretation of biological statistics of fish populations. Bulletin Fisheries Research Board of Canada, 382.

22. Rosa H (1958): A synopsis of the biological data on the tench, Tinca tinca (L., 1758). FAO 58, 951.

23. Sinis AI, Meunier FJ, Vieillot HF (1999): Comparision of sclaes, opercular bones, and Vertabrae to Determine Age and Population Structure in Tench, Tinca tinca (L., 1758) (Pisces, teleostei), Israel J Zool, 45, 453-465.

24. Sparre P, Venema SC (1992): Intoduction to tropical fish stock assessment. Part 1. Manual. FAO Fisheries Technical Paper no 306. (Rev. 1). FAO, Rome, pp 376.

25. Wright RM, Giles N (1991): The population biology of tench, Tinca tinca (L.) in two gravel pit lakes. J Fish Biol, 38, 17-28.

Geliş tarihi: 20.12.2013 / Kabul tarihi: 31.03.2014
Address for correspondence:
Dr. Semra Benzer
Gazi University, Faculty of Education,
Department of Science Education, Teknikokullar, Ankara-TURKEY.
e-mail:sbenzer@gazi.edu.trsbenzer@gmail.com 